\title{
EVALUATION OF ALTERNATIVE CONTAINERS TO DETERMINING THE WORKING WIDTH OF FERTILIZER SPREADERS
}

\author{
MARCELO A. PRIMO ${ }^{1}$, FLAVIO GURGACZ ${ }^{2}$, VILSON L. KUNZ ${ }^{3}$, LUCAS I. PRIMO ${ }^{4}$, \\ FERNANDO FURLAN ${ }^{4}$, SUEDÊMIO L. SILVA ${ }^{5}$, ANTONIO GABRIEL FILHO ${ }^{6}$
}

\begin{abstract}
Farmers have difficult of determining the evenness of transverse distribution and the working width, due the tests with this aim require equipments and complex methodologies. So, this study evaluates some alternative containers with the aim to allow a more accessible adjustment of the full width of the solid fertilizer spreaders. Four different containers were tested: i) standard container constructed in accordance with ISO 5690/1; ii) container of polyethylene (plastic trays) with screen shading to prevent the ricochet of material; iii) containers composed by boxes of longlife milk, and iv) containers composed by flowerpots (number 3.5). Also, three different spreaders were used for the tests. Alternative containers showed greater retention of particles than the standardized containers. The full width of work obtained for the coefficients of variation of 12.5; $15 ; 17.5$ and $20 \%$, ranged due the containers in the different pathways. The flowerpots of polyethylene showed similar results to the standardized containers. The heights of the containers were more important for its efficiency than its area of collection.
\end{abstract}

KEYWORDS: fertilization at throw, agricultural machines, agricultural mechanization.

\section{COLETORES ALTERNATIVOS PARA A DETERMINAÇÃO DA LARGURA DE TRABALHO DE DISTRIBUIDORES DE FERTILIZANTES SÓLIDOS A LANÇO}

RESUMO: Os ensaios de largura de trabalho e uniformidade de distribuição são de difícil execução para o agricultor por exigirem equipamentos, recursos e métodos complexos. Portanto, este trabalho teve como objetivo avaliar coletores alternativos para tornar mais acessível a regulagem e a avaliação de distribuidores de fertilizantes sólidos a lanço. Foram utilizados quatro diferentes conjuntos de coletores: i) coletores construídos segundo a norma ISO 5690/1; ii) coletores de polietileno (bandejas plásticas) com tela de sombreamento para evitar o ricochete de material; iii) coletores formados por caixas de leite longa vida, e iv) coletores formados por vasos de polietileno (número 3,5). Também foram utilizados três diferentes distribuidores para as avaliações. Os coletores alternativos apresentaram maior retenção de partículas que os coletores normatizados. A largura efetiva de trabalho obtida para os coeficientes de variação de 12,$5 ; 15 ; 17,5$ e $20 \%$ variou entre os coletores nos diferentes percursos. O coletor que mais se assemelhou à norma foram os vasos de polietileno. Constatou-se que a altura dos coletores foi mais importante para sua eficiência do que a sua área de coleta.

PALAVRAS-CHAVE: adubação a lanço, máquinas agrícolas, mecanização agrícola.

\footnotetext{
${ }^{1}$ Agronomy Engineer, on Mastership program of Agriculture Engineering, Agroindustrial Systems, UNIOESTE, Cascavel - PR, Brazil, Phone: (0XX45) 9968-6169, marceloalanprimo@yahoo.com.br. on CAPES studentship.

${ }^{2}$ Agronomy Engineer, Master in Agriculture Engineering, Agroindustrial Systems, UNIOESTE, Cascavel - PR, Brazil.

${ }^{3}$ Agronomy Engineer, on Doctorship program in Agronomy, FCA/UNESP, Botucatu - SP, Brazil.

${ }^{4}$ Agronomy student, UNIOESTE, Marechal Candido Rondon - PR, Brazil.

${ }^{5}$ Agricultural Engineer, Assistant Professor, CCET, UNIOESTE, Cascavel - PR, Brazil.

${ }^{6}$ Agronomy Engineer, Assistant Professor, CCET, UNIOESTE, Cascavel - PR, Brazil.

Received by Editorial Board on September, 27, 2007
}

Approved by Editorial Board on June, 17, 2008 


\section{INTRODUCTION}

For the achievement of the agricultural productivity aims in a certain area, the proper inputs are to be used in the prescribed dosage. However, there is no use the correct selection of inputs and fertilizers, nor the precise dosage estimations if the product distribution operation in the area is not even. The consequence is the commitment of the yield productivity and the fertilizers waste, which become little effective (MOLIN \& MAZZOTI, 2000). The excessive fertilization can be harmful for the plants, in addition of the unneeded expenditure of the product; whereas, the lack will certainly result into the productivity decrease due to the absence of nutrients.

MILAN \& GADANHA JÚNIOR (1996) presented methodology for the characterization of those applicators towards the determination of the distribution profile and the effective width of the application band, by means standardized collectors, weight of the collected material and the necessary calculations. The width of the application band is dependent on the product and on its physical features, whose determination is a hard task.

Various works have been performed to characterize the performance of the machines on spread solid fertilizers application, among of which, the transversal distribution essay can be regarded one of the most laborious., which demanded higher time consuming, both in the data collection and in the results analysis. This essay is performed under the availability on field with several standardized collectors, aimed to collect the material distributed in that area. The amounts obtained form each collector are heavy, thus the product transversal distribution curve was obtained. This piece of information is used to determine the work width of the machine for the work condition (MOLIN \& MAZZOTTI, 2000).

In conformity with MOLIN \& RUIZ (1999), the spread fertilizers require some basic balances towards the work outflow and width. The work width is determined as the minimal regulation function of the required dosage, obtained from an overlaying with the past adjacent ones. The definition of this work width or effective width is obtained by means of essays. This essay is of hard performance by the agricultor, because they demand equipment, resources and method that are not in reach of the ordinary user.

The purpose of this paper is to analyze the alternative collectors to turn the regulation and the spread solid fertilizers distributor evaluation more viable.

\section{MATERIAL AND METHODS}

The work was carried out in the place of FAPA - Fundação Agrária de Pesquisa Agropecuária, based in the City of located in Entre Rios, in the town of Guarapuava - PR, Brazil. This Foundation is based at $25^{\circ} 55^{\prime}$ 'of south latitude, at $51^{\circ} 48^{\prime}$ west longitude at the altitude of $1.095 \mathrm{~m}$. The essay was conducted in a plain area, covered with rocks, whose trees barriers was also present., and that permitted the minimization of the wind conditions that may have affected the profile of the longitudinal and transversal distribution of the solid fertilizers distributors.

Four types of collectors were used:

- Polyethylene standardized collector following the norm ISO 5690/1, at the dimensions of $1 \times 0.25 \mathrm{~m}$ and depth of $0.15 \mathrm{~m}$, thereafter called "Norma";

- Polyethylene tray collector at the dimensions of $0.36 \times 0.24 \mathrm{~m}$ and depth of $0.075 \mathrm{~m}$, to be called "Tray". To avoid the material ricochet material out of this tray, a screen at $30 \%$ of shade was used, cut into pieces with the same dimensions of the tray and placed at their bottoms. This material was mentioned by MOLIN \& MAZOTTI (2000), as an effective shock absorber of the particles ricochet;

- Boxes of long life milk with one of the side is cut. The boxes were united in number of five by staples and adhesive tape, forming collectors of $0.5 \times 0.165 \mathrm{~m}$ at depth of $0.06 \mathrm{~m}$, being called by "Milk Boxes". 
- Polyethylene flowerpots (number 3.5), at $0.15 \mathrm{~m}$ of height, $0.19 \mathrm{~m}$ of diameter at the upper part and $0.14 \mathrm{~m}$ on the ground, thereafter called as "Flowerpot". The present holes on the ground of the flowerpots were covered with adhesive tape.

The collectors were transversally distributed in the sense of the move of the tractor and distributor set, whose edges of each collector were next to the neighbor ones. Each spread of the tractor distributor set carried out the application of the four treatments, which were placed in lines. Thereafter, the application was evened, thus carried out at a single time.

A Ford tractor was used, model 7630, working on the sixth gear, at the speed of $2.22 \mathrm{~m} \mathrm{~s}^{-1}$ and at angular speed of 1,900 rotations $\mathrm{min}^{-1}$ in the engine, what granted the rotation of $540 \mathrm{rpm}$ of the potency uptake, and the distributors were connected to this tractor. The distributors used were: Distributor model Lancer Master1200; distributor model brand Sembra 1300-P AH, e and distributor model Rota Flow. All the distributors presented the mechanism of two discs.

As the rulings were made in accordance with the operator's handbook. The distributors were ruled at $100 \mathrm{~kg} \mathrm{ha}^{-1}$, to obtain the work width at $18 \mathrm{~m}$, which is usually applied by the producers of the area. The latter gave the distributor for the evaluation purpose.

The used fertilizer was the common urea, and the same fertilizers lots were used for all essays. Two turns were made for the collector s and after the individualized material was collected and packed into plastic packages, which were dully, identified with the type of collector at the transversal positions. Both turns were carried out for making the product quantity more significant, thus facilitating the material collection and weight.

The values obtained in grams for each collector were transformed into kilogram by hectare, taking into account the area for each one. From theses data on the analyses to determine the decomposition band was performed, by using the program Adulanço 2.0, proposed by MOLIN $t$ al. (1992). For the charts composition with the comparatives and methodologies, both the Excel and the software Minitab 14.0. Were used.

The procedure adopted by Adulanço 2.0 followed the same one recommended by MILAN \& GADANHA JÚNIOR (1996), based on the variation coefficient (C.V.). Therefore, the successive recovering simulation was performed with the values obtained firm the collectors and CV\% is calculated for each recovering situation for both systems, which can be carried out on field.

By the use of Sisvar software, the variance analysis and the average comparisons were performed, thus applying the Tukey test $5 \%$ of probability. The adopted experience design was the factorial one at $4 \times 3$ (three alternative collectors + the collector of the norm $x$ three distributors), in which the main aim was the comparison of the collectors. In the results, the data were disregarded when there was interaction among the factors.

\section{RESULTS AND DISCUSSION}

\section{The local climate conditions}

The environmental conditions measured in the area and time of the essay on each machine is present in Table 1.

TABLE 1. Climate conditions in the area of the essay.

\begin{tabular}{|c|c|c|c|c|c|c|c|c|c|c|}
\hline \multirow{4}{*}{ Variables } & \multirow{4}{*}{ Unit } & \multicolumn{9}{|c|}{ Climate Conditions } \\
\hline & & \multicolumn{9}{|c|}{ Distributors/Essays } \\
\hline & & \multicolumn{3}{|c|}{ Rota Flow } & \multicolumn{3}{|c|}{ Sembra } & \multicolumn{3}{|c|}{ Lancer } \\
\hline & & 1 & 2 & 3 & 1 & 2 & 3 & 1 & 2 & 3 \\
\hline Umd & $\%$ & 57.6 & 59.3 & 55.9 & 41.3 & 42.0 & 43.0 & 35.4 & 57.0 & 53.4 \\
\hline $\mathrm{VVt}$ & $\mathrm{m} \mathrm{s}^{-1}$ & 1.3 & 2.5 & 0.0 & 1.9 & 1.0 & 0.0 & 1.4 & 0.0 & 1.0 \\
\hline Temp. & ${ }^{\circ} \mathrm{C}$ & 19.1 & 17.1 & 21.0 & 27.5 & 24.0 & 27.0 & 23.0 & 18.5 & 18.9 \\
\hline
\end{tabular}

Umd - relative humidity of the air; VVt - speed of the wind; Temp - temperature. 
In accordance with the methodology proposed by MILAN \& GADANHA JÚNIOR (1996), the values for the speed of the wind were in accordance with the maximal of $2 \mathrm{~m} \mathrm{~s}^{-1}$, which was proposed by the authors, whose unique unfavorable condition was present in the second repetition of the Rota Flow distributor, in which the speed of the wind was measured at $2.5 \mathrm{~m} \mathrm{~s}^{-1}$. In some moments, the influence of the wind was null. The other environmental conditions were within the standards stipulated by the norms by the time the measures were performed.

\section{Transversal distribution profile}

By analyzing the charts that show the transversal distribution profile for each machine (Figures 1; 2 and 3), it is noticed that the curves, each one indicates a type of collector, do not coincide, however, they follow the same trend. All the collectors present the same trend of maxima and minimal peaks at the same positions along the urea distribution band.

The difference among the curves occurs owing to greater retention of material in the collectors made of milk boxes and the plastic trays. The greater collection is supposed to be due the material ricochet into the collectors, for, at the moment of the launching by the distributor, the particle would acquire great speed and followed the journey (random) after reaching the soil at the place of the essay. This effect was noticed by PRIMO (2004), in an experience performed on the stone pavements. In this experience, the surface was made just of rocks, which theoretically would diminish the ricochet effect of the fertilizing particles. This statement is based on the reports by PATTERSON (1964) cited by WHITNEY et al. (1987), who observed that $40 \%$ of the material comes from the ricochet into the collectors, from the concrete floor, with the use of collectors of 0.15 high (higher than the trays and the boxes of milk).

In the collectors made of the polyethylene flowerpots, which had the height similar to the standardized collectors, the curves presented to be very close. This way, it can be alleged that the effect of the higher collection due to the ricochet is due to the difference of the height among the collectors.

In Figure 2, in reference to the Sembra distributor, it was revealed that there was a higher concentration of the urea distribution on the left side of the machine. This variation may be due to the higher opening of the dosing plate on that side, once this machine has the distributor mechanism of two discs.

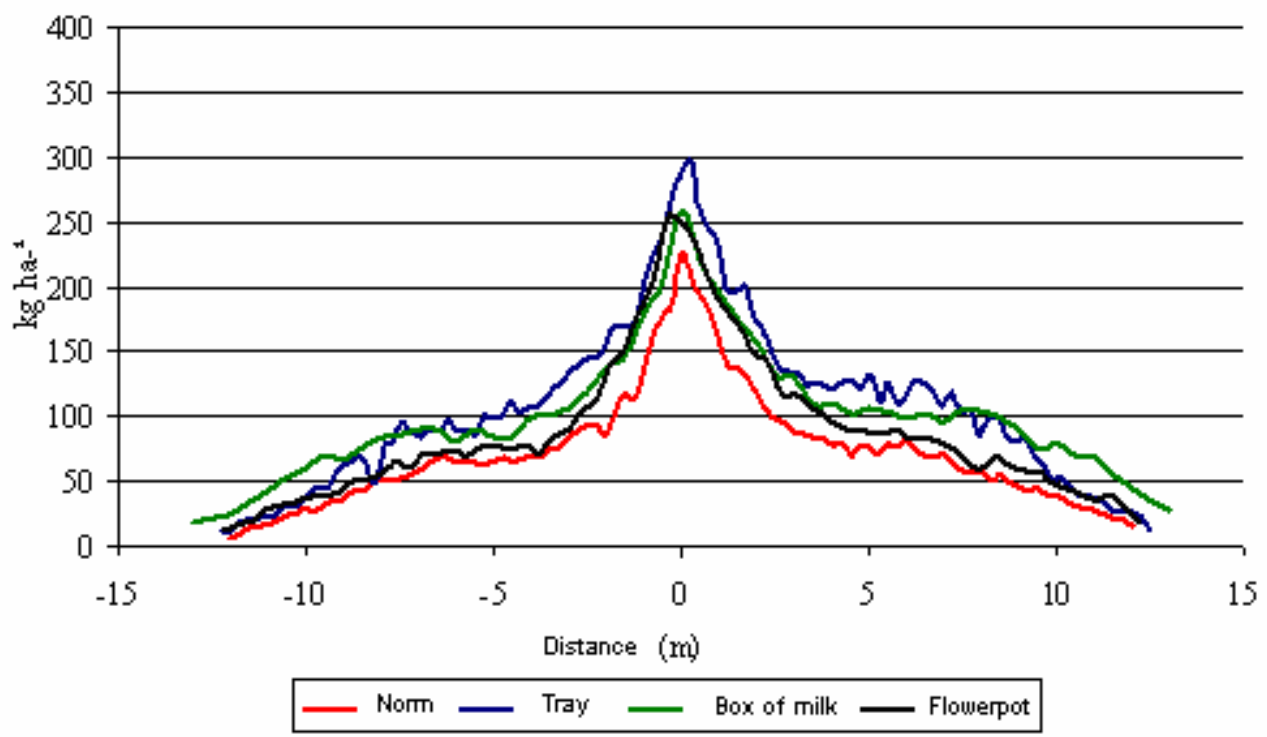

FIGURE 1. Urea transversal distribution obtained with the different collectors and Lancer distributor. 


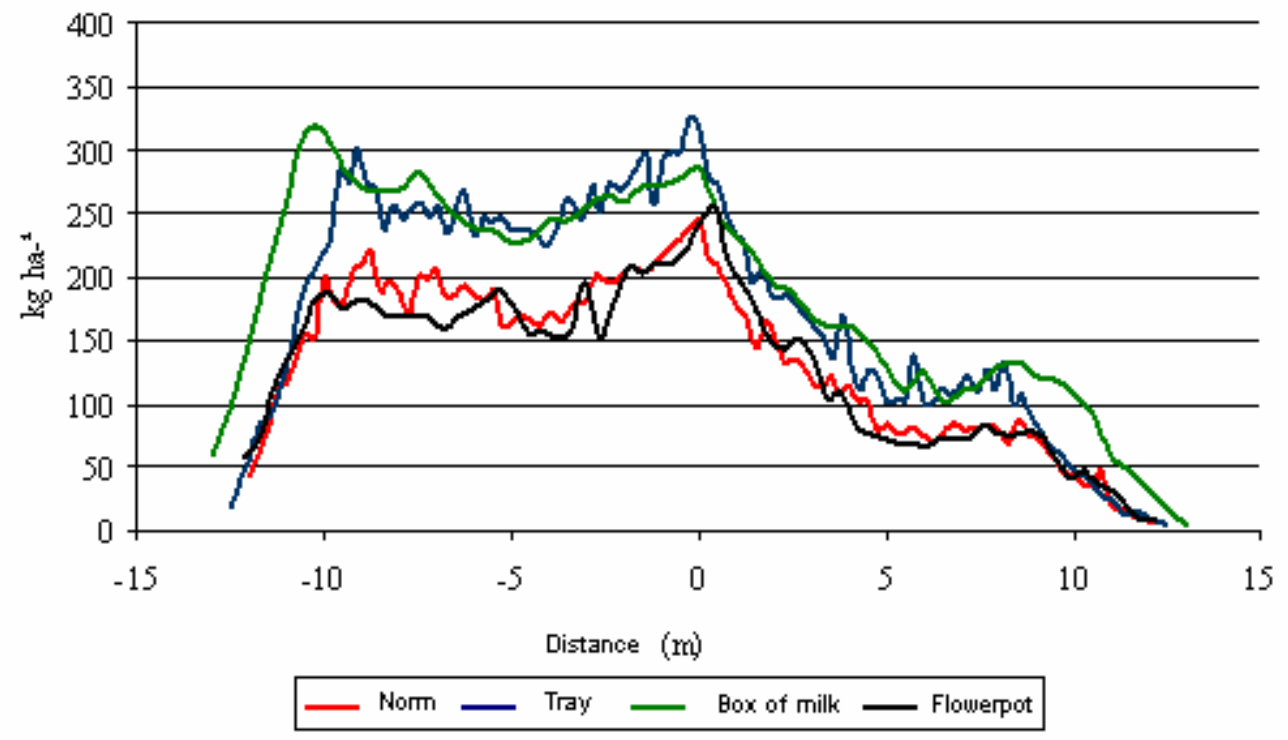

FIGURE 2. Urea transversal distribution obtained with the different collectors and Sembra distributor.

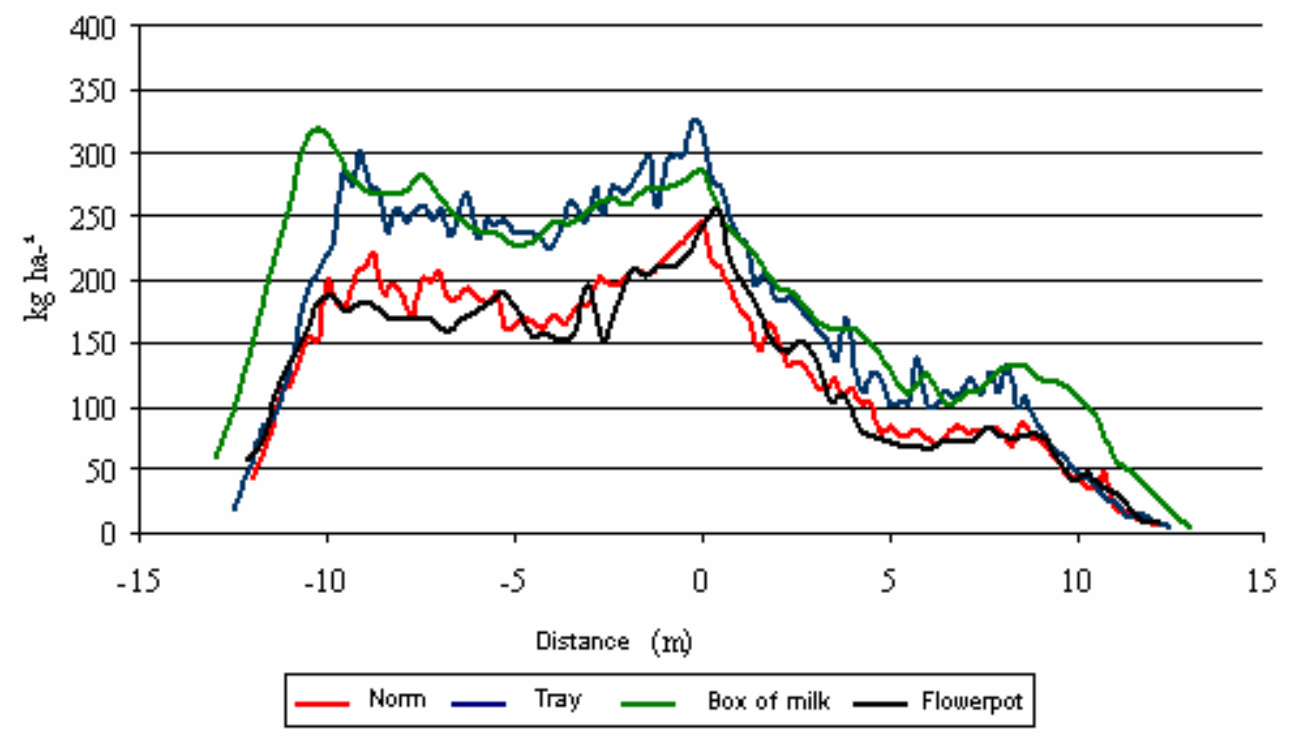

FIGURE 3. Urea transversal distribution obtained with the different collectors and Rota Flow distributor.

\section{Comparison between the alternative and the standardized collectors}

In the Figures 4; 5 and 6, the percentage difference of the urea distribution is shown between the alternative collectors, when compared to the standard ones, within the distribution profile for each machine. In these charts, the value 0 of the profile shows the left edge and the value of $25 \mathrm{~m}$ shows the right edge.

The flowerpots represent a relative collection that is very similar to the Norm collectors. The latter differs more or less between $50 \%$ in some points of the distribution profile ranged mostly at the difference of $20 \%$.

Conversely, the trays oscillated much at their collection values, whose difference ranged from 50 to $150 \%$ in relation to the Norm. The relative differences of the tray oscillated in a diversely within the profile with the closing trend to the Norm in the application central band.

The Boxes of milk presented a very high oscillation in relation to its standardized collector, with the trend of approaching the band application center. At the edge of the bands, the milk boxes collectors presented the material retention difference higher than $150 \%$. 


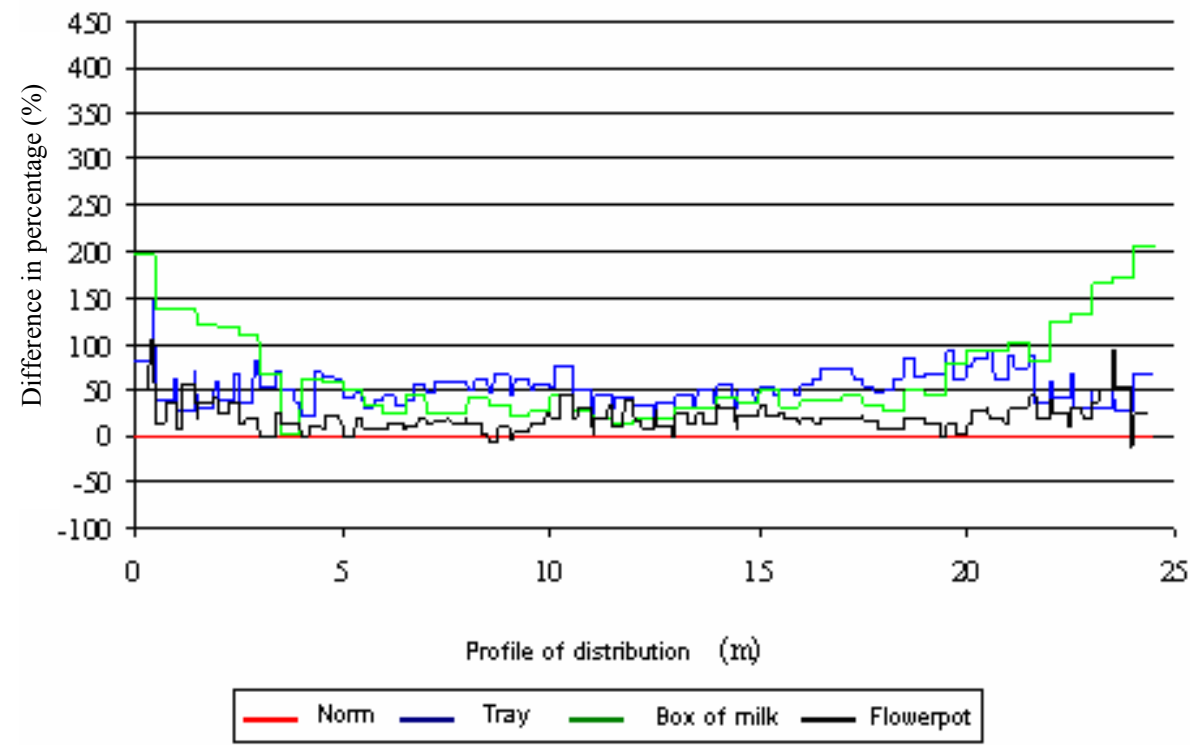

FIGURE 4. Comparison between the collectors and Lancer distributor.

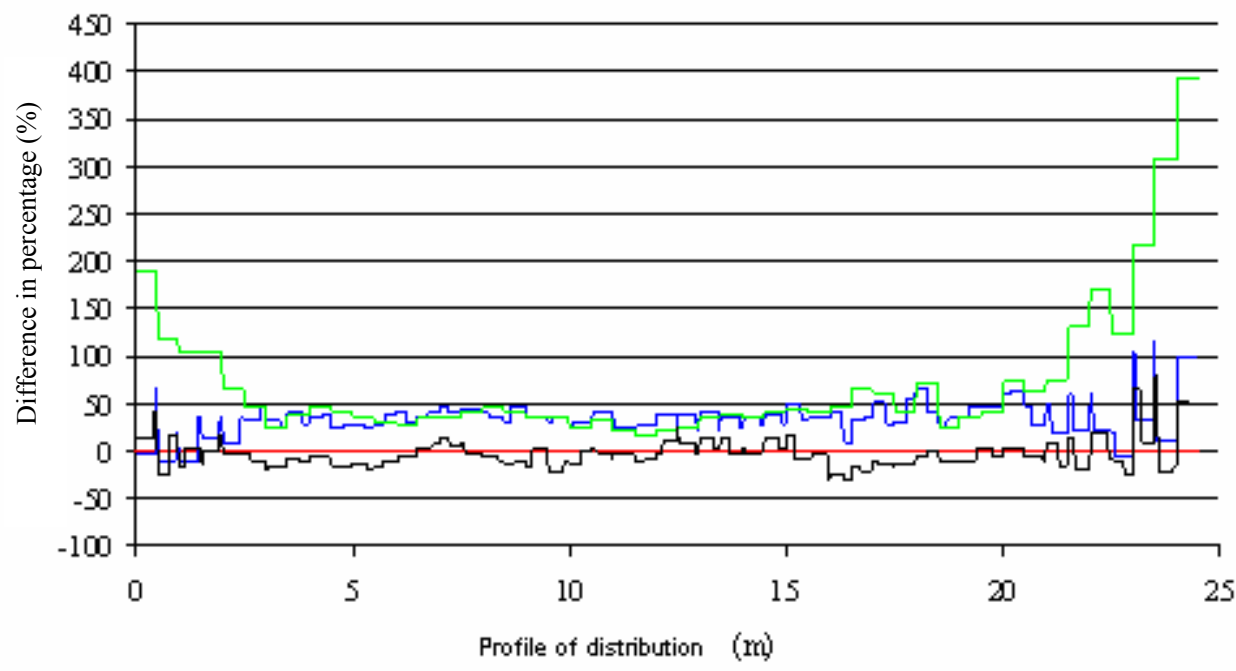

— Norm — Tray $\longrightarrow$ Box of milk — Flowerpot

FIGURE 5. Comparison between the collectors in Sembra distributor.

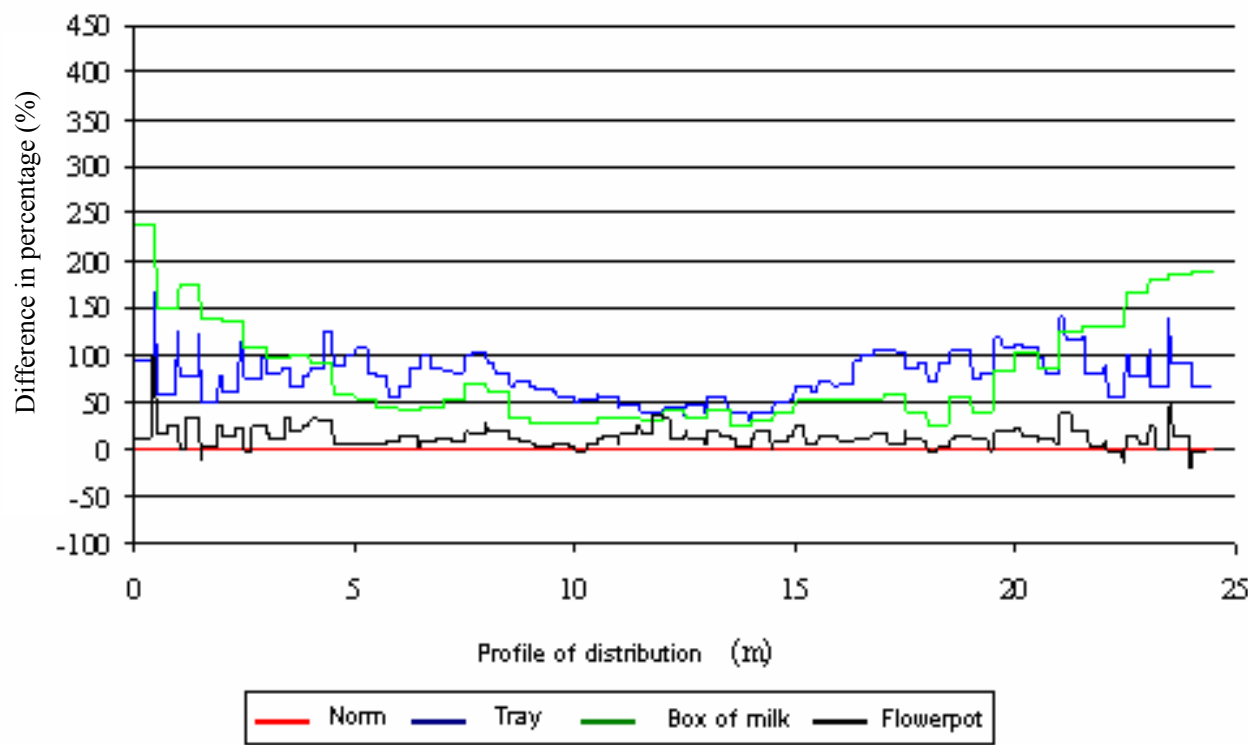

FIGURE 6. Comparison among the collectors in the Rota Flow distributor. 
MOLIN \& MAZZOTTI (2000) by having worked with the standardized collectors with protection plates to avoid the ricochet of the particles, they observed that in the edges of the application band there was the trend of smaller amount of collected fertilizer. In conformity with the authors, it can occur in relation with the ricochet of the particles out of the collectors. In the middle band, where the particles launching direction is predominantly coincident with the longitudinal axis, the effect of the ricochet was not detected, thus resulting into a higher collection.

The box of milk collectors stored even more urea than the standardized ones, because their longitudinal axis were coincident with the launching of the particles of the edges, once the form in which they were placed on the ground granted them the higher width $(0.165 \mathrm{~m})$ when compared to the other forms, and they presented subdivisions that diminished even more the effect of the ricochet on the particles out of the collectors. In addition to this factor, the low height of this collector increased the capacity of the collection.

\section{Effective work width for diverse coefficients of variation}

To check the effectiveness of the collectors in comparison with the Norm ones, some maximal variation coefficients were defined, of which resulted into even work width. Firstly, the German norm cited by MILAN \& GADANHA JÚNIOR (1996), was taken as standard to establish the maximal variation coefficient of $12.5 \%$. Other variations coefficients were used, such as $15 \%$; $17.5 \%$ and $20 \%$, the latter was cited in the Brazilian literature as the maximal variation coefficient (MOLIN \& MENEGATTI, 2003).

At the variation coefficient of $12.5 \%$ (Table 2), in the continuous and alternate left systems there was no interaction between the factors (collector and distributor), and the collectors were all similar statistically. There was interaction between the factors in the alternate right heading system.

TABLE 1. Effective mean widths (m) for C.V. at $12.5 \%$ in the three journeys of the distribution.

\begin{tabular}{cccccl}
\hline \multirow{2}{*}{ Collector } & \multirow{2}{*}{ Continuous } & \multirow{2}{*}{ Left Alternate } & \multicolumn{3}{c}{ Right Alternate* } \\
\cline { 4 - 6 } & & & Lancer & Sembra & Rota Flow \\
\hline Norm & $11.1 \mathrm{~A}$ & $14.0 \mathrm{~A}$ & $5.3 \mathrm{Aa}$ & $9.7 \mathrm{ABab}$ & $12.7 \mathrm{Ab}$ \\
Trays & $11.0 \mathrm{~A}$ & $13.3 \mathrm{~A}$ & $5.7 \mathrm{Aa}$ & $9.3 \mathrm{Aa}$ & $21.7 \mathrm{Bb}$ \\
Boxes of Milk & $13.0 \mathrm{~A}$ & $17.5 \mathrm{~A}$ & $15.0 \mathrm{Ba}$ & $15.3 \mathrm{Ba}$ & $16.7 \mathrm{ABa}$ \\
Flowerpot & $9.8 \mathrm{~A}$ & $12.2 \mathrm{~A}$ & $6.0 \mathrm{Aa}$ & $9.0 \mathrm{Aab}$ & $13.0 \mathrm{Ab}$ \\
\hline C.V.\% & 31.7 & 29.8 & 22.3 & & \\
\hline DMS & 4.6 & 5.5 & Collector $=3.4$ & Distributor $=2.6$ \\
\hline
\end{tabular}

Similar capital letters do not differ from the values in the column, in conformity with Tukey test at 5\%. Similar capital letters do not differ from the values in the line, in conformity to Tukey test at $5 \%$.

In this case, the collectors formed by the boxes of milk resulted into work widths greater and different statistically from the other collectors for the distributors Lancer and Sembra. For the distributor Rota Flow, the boxes of milk were statistically similar to the other collectors, however, the collector formed by trays resulted into a higher work width.

By regarding the variation coefficient at $15 \%$ (Table 3 ), the continuous system presented a significant interaction among the evaluated factors. There was a statistic difference among the collectors in the distributors Lancer e Rota Flow. As for the distributor Sembra, all the collectors presented similar effective work width at the average of $13 \mathrm{~m}$.

Both in the left and right alternate journeys, there was interaction between the collector and the distributor. In the left alternate journey, the collectors differed among themselves however, in statistic terms, they presented to be equal to the standardized collector. In the right alternate journey, just the Flowerpot collector was similar to the Norm one. 
TABLE 2. Effective mean widths (m) for the C.V. at 15\% in the three journeys of the distribution.

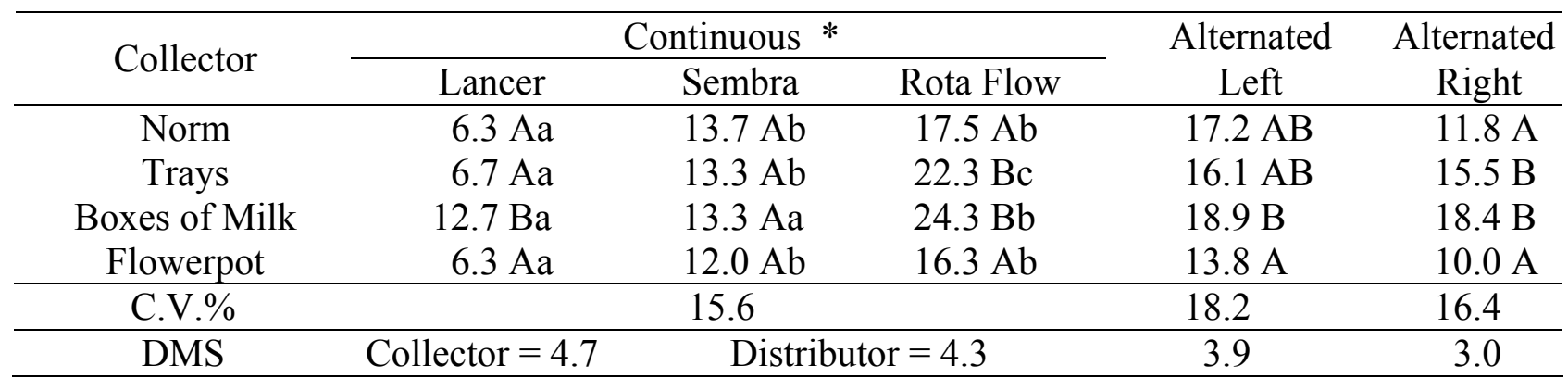

Similar capital letters do not differ from the values in the column, in conformity with Tukey test at $5 \%$.

Similar capital letters do not differ from the values in the line, in conformity to Tukey test at $5 \%$.

* Significant interaction between the factors (collectors and distributors) is in study.

Similarly to the variation coefficient at $15 \%$, for the one at $17.5 \%$ (Table 4 ), the continuous system presented interaction among the factors, and there was interaction in the other systems.

TABLE 3. Effective mean widths $(\mathrm{m})$ for the C.V. at $17.5 \%$ in the three distribution journeys.

\begin{tabular}{|c|c|c|c|c|c|}
\hline \multirow{2}{*}{ Collector } & \multicolumn{3}{|c|}{ Continuous $*$} & \multirow{2}{*}{$\begin{array}{c}\text { Alternate } \\
\text { Left }\end{array}$} & \multirow{2}{*}{$\begin{array}{c}\text { Alternate } \\
\text { Right }\end{array}$} \\
\hline & Lancer & Sembra & Rota Flow & & \\
\hline Norm & $8.7 \mathrm{Aa}$ & $14.3 \mathrm{Ab}$ & $22.0 \mathrm{Ac}$ & $18.1 \mathrm{AB}$ & $14.9 \mathrm{AB}$ \\
\hline Trays & $13.3 \mathrm{Ba}$ & $14.0 \mathrm{Aa}$ & $22.3 \mathrm{ABb}$ & $18.5 \mathrm{AB}$ & 16.1 BC \\
\hline Boxes of Milk & $15.0 \mathrm{Ba}$ & $14.0 \mathrm{Aa}$ & $24.7 \mathrm{Bb}$ & $21.2 \mathrm{~B}$ & $19.1 \mathrm{C}$ \\
\hline Flowerpot & $7.0 \mathrm{Aa}$ & $13.7 \mathrm{Ab}$ & $20.9 \mathrm{Ab}$ & $16.2 \mathrm{~A}$ & $12.0 \mathrm{~A}$ \\
\hline C.V.\% & \multicolumn{3}{|c|}{8.2} & 14.4 & 16.3 \\
\hline DMS & \multicolumn{3}{|c|}{ Distributor $=3.5$} & 3.5 & 3.3 \\
\hline
\end{tabular}

Similar capital letters do not differ from the values in the column, in conformity with Tukey test at $5 \%$.

Similar capital letters do not differ from the values in the line, in conformity to Tukey test at $5 \%$.

* Significant interaction between the factors (collectors and distributors) is in study.

The work widths presented to be very low, taking into account the purpose of ruling a band of $18 \mathrm{~m}$. Even the variation coefficient of $20 \%$ was not able to reach the pre-determined width, thus it remained very distant form the one recommended by the German rule cited by MILAN \& GADANHA JÚNIOR (1996).

In a fixed variation coefficient at $20 \%$ (Table 5), there was no interaction among the factors at no system. The collectors were all statistically similar to the standardized collectors, except for the right alternate journey, in which only collectors formed by boxes of milk were statistically different form the standardized ones.

TABLE 4. Effective mean widths (m) for the C.V. at 20\% in the three distributions journeys.

\begin{tabular}{cccc}
\hline Collector & Continuous & Left Alternate & Right Alternate \\
\hline Norm & $16.2 \mathrm{AB}$ & $19.2 \mathrm{AB}$ & $14.7 \mathrm{AB}$ \\
Trays & $16.2 \mathrm{AB}$ & $20.1 \mathrm{~B}$ & $17.3 \mathrm{BC}$ \\
Boxes of Milk & $18.7 \mathrm{~B}$ & $21.2 \mathrm{~B}$ & $19.7 \mathrm{C}$ \\
Flowerpot & $15.7 \mathrm{~A}$ & $17.8 \mathrm{~A}$ & $13.9 \mathrm{~A}$ \\
\hline C.V.\% & 12.5 & 8.1 & 15.2 \\
\hline DMS & 2.7 & 2.1 & 3.2 \\
\hline
\end{tabular}

Similar capital letters do not differ from the values in the column, in conformity to Tukey test at 5\%.

\section{Maximal width for $50 \%$ of the sample weight}

Another methodology proposed by MILAN \& GADANHA JÚNIOR (1996) for the obtention of the work width is by means of the application of the collected weight from each collector. By 
means of the distribution profile point (whereby the collector is found), of which represents $50 \%$ of the maximal value, the work width s found to be multiplied by two.

The comparisons of the maximal width averages found by the use of this methodology are referred to in Table 6. There was no interaction among the evaluated factors, whose statistic difference was seen to be present among the treatments for each factor.

TABLE 6. Maximal width used for the determination at $50 \%$ of the maximal mass.

\begin{tabular}{cccc}
\hline Collector & Average & Distributor & Average \\
\hline Norm & $11.6 \mathrm{~A}$ & Lancer & $4.9 \mathrm{~A}$ \\
Trays & $13.9 \mathrm{~B}$ & Sembra & $14.7 \mathrm{~B}$ \\
Boxes of Milk & $14.2 \mathrm{~B}$ & Rota Flow & $19.0 \mathrm{C}$ \\
Flowerpot & $11.8 \mathrm{~A}$ & & \\
\hline C.V.\%=11.9 & DMS $=2.0$ & & DMS $=1.6$ \\
\hline
\end{tabular}

Similar capital letters do not differ from the values in the column, in conformity with Tukey test at $5 \%$.

Only were the collectors formed by the polyethylene flowerpots checked to be statistically similar to the standardized collectors. The alternative collectors formed by laboratorial trays and by boxes of milk were statistically similar among them, however they differed from the standardized collectors and the polyethylene flowerpot. This fact was attributed to the collectors height at $0.15 \mathrm{~m}$ and $0.14 \mathrm{~m}$ for the standardized collectors and for the flowerpots in respective; and at $0.075 \mathrm{~m}$ and $0.060 \mathrm{~m}$ for the collectors formed by trays and boxes of milk respectively. Owing to the higher retention of the material in the lowest collectors, the distribution profile was modified, thus affecting also the work width, once calculated by this method.

The significant differences found among the distributors were presumably due to the different characteristics of the launching device and mainly by the interaction between the physical characteristics of the fertilizers and the rulings determined by the instruction handbook.

\section{CONCLUSIONS}

The collectors presented a differential behavior among the distributors and the evaluated collectors, as well as the different results in the adopted systems, that is to say, they did not present constant results.

The paper showed that the collectors should have a minimal height, however, it was proven that the collection area is not a limiting factor for the use of alternative collectors.

Taking into account the results obtained, the flowerpot collector was statistically similar to the one of ISO 5690/1 norm for all distributors and systems studied. Therefore, this collector could be used without restrictions for the ruling of the spread distributors at the cost advantage in relation to the Norm collector one.

\section{REFERENCES}

ISO. INTERNATIONAL STANDARD. Equipment for distributing fertilizer: test methods: Full width fertilizer distributors. 5690/1. 1982 (E). Geneve: International Standards Organization, 1982. part 1 .

MILAN, M.; GADANHA JÚNIOR, C.D. Ensaio \& Certificação das máquinas para aplicação de adubos e corretivos. In: MIALHE, L.G. Máquinas agrícolas: Ensaios \& Certificações. Piracicaba: Fundação de Estudos Agrários “Luiz de Queiroz", Universidade de São Paulo, 1996. p.515-50.

MOLIN, J.P.; COELHO, J.L.D.; VASARHELYI, A. Programa computacional para análise de distribuição transversal em aplicadores de fertilizantes e corretivos a lanço. In: CONGRESSO BRASILEIRO DE ENGENHARIA AGRÍCOLA, 21., SIMPÓSIO DE ENGENHARIA 
AGRÍCOLA DO CONE SUL, 1., 1992, Santa Maria. Anais... Santa Maria: Sociedade Brasileira de Engenharia Agrícola, 1992. v.4, p.2.097-3003.

MOLIN, J.P.; MAZOTTI, H.C. Influência da utilização e do tipo de amortecedores de ricochete em ensaios de aplicadores a lanço. Revista Brasileira de Engenharia Agrícola e Ambiental, Campina Grande, v.4, n.2, p.281-5, 2000.

MOLIN, J.P.; MENEGATTI, A.A. Desempenho de distribuidora a lanço com doses variáveis de uréia. Engenharia Agrícola, Jaboticabal, v.23, n.2, p.290-9, 2003.

MOLIN, J.P.; RUIZ, E.R.S. Validação de métodos simplificadores de determinação da largura efetiva para distribuidores de fertilizantes e corretivos. In: CONGRESSO BRASILEIRO DE ENGENHARIA AGRÍCOLA, 28., 1999, Pelotas. Anais... Pelotas: Sociedade Brasileira de Engenharia Agrícola, 1999. 1 CD-ROM.

PRIMO, M.A. Ensaio de coletores alternativos para a determinação da largura de distribuição de uréia a lanço. 2004. 34 f. Monografia (Trabalho de Graduação em Agronomia) - Universidade Estadual do Oeste do Paraná, Marechal Cândido Rondon, 2004.

WHITNEY, R.W.; ROTH, L.O.; KULHMAN, D.K. Performance of selected granular collectors. Transactions of the ASAE, St. Joseph, v.30, n.2, p.338-42, 1987. 